\title{
KELEMBAGAAN KOMUNITAS DALAM PEMBERDAYAAN RUMAH TANGGA PETANI MISKIN DI DESA KAPITA KECAMATAN BANGKALA KABUPATEN JENEPONTO
}

\author{
Andriana, Abdul Mahsyar \\ Universitas Muhamadiyah Makassar \\ e-mail: andrianaana28@gmail.com
}

\begin{abstract}
Community institutionalization in empowering the household community of poor farmers in Kapita Village, Bangkala District, Jeneponto Regency, in the implementation, there are still many obstacles that have not run optimally.The purpose of this research is to know the institutional community in community empowerment (household) poor farmers in the village of capita. This research uses descriptive qualitative approach, which uses a method of interviewing, observation, documentation, and libraries to explore studies on existing groups are able to become a strong community and institutional work related to community empowerment that has been running in the village of Capita into a more directional and cutting edge. Empowerment will affect direct interaction, relationships, goals and setup rules in the group created good, a group that is in the capita as farmers group, goat and cattle still need in language use and given a motivation in the development of the group in order to be effective, efisen bias, just and prosperous
\end{abstract}

Keywords: Institutional, Community, Community Empowerment, Poor Farmer Households

\begin{abstract}
Abstrak
Kelembagaan komunitas dalam pemberdayaan masyarakat rumah tangga petani miskin di Desa Kapita Kecamatan Bangkala Kabupaten Jeneponto dalam pelaksanaannya masih dijumpai banyak kendala sehingga belum berjalan secara optimal. Penelitian ini bertujuan untuk mengetahui kelembagaan komunitas dalam pemberdayaan masyarakat (rumah tangga) petani miskin di Desa Kapita. Penelitian ini menggunakan pendekatan deskriptif kualitatif, yang menggunakan metode wawancara, observasi, dokumentasi, dan studi kepustakaan untuk mengeksplorasi tentang kelompok-kelompok yang ada apakah mampu menjadi kelembagaan komunitas yang kuat dan melembaga terkait dengan pemberdayaan masyarakat yang telah berjalan di Desa Kapita ke jalan yang lebih terarah dan terdepan. Pemberdayaan yang baik akan mempengaruhi langsung interaksi, tata hubungan, tujuan dan penataan aturan dalam kelompok terjalin baik, kelompok yang ada di kapita seperti kelompok tani, dan ternak kambing masih perlu di dampingi dan diberi motivasi dalam pengembangan kelompoknya agar bias efektif, efisen, adil dan sejahtera.
\end{abstract}

Kata Kunci : Kelembagaan, Komunitas, Pemberdayaan Masyarakat, Petani Miskin

\section{PENDAHULUAN}

Indonesia merupakan Negara dengan jumlah rumah tangga petani yang besar. Pada tahun 2003 jumlah rumah tangga petani mencapai 31 juta namun pada tahun 2013 menurun menjadi 26 juta rumah tangga petani (BPS 2013). Kemiskinan bukan masalah baru, namun sudah ada sejak masa penjajahan dan sampai saat ini kemiskinan masih menjadi masalah yang belum teratasi. Di negara berkembang seperti di Indonesia kemiskinan menjadi masalah utama yang harus diminimalisir, bahkan di negara maju pun masih ada masyarakatnya yang tergolong miskin, oleh sebab itu kemiskinan menjadi masalah dunia yang harus diperhatikan (Daraba, 2017:52).

Penerapan modernisasi sebagai peradigma pembangunan di segala bidang termasuk di Indonesia selama 32 tahun, disatu sisi telah membawa kemajuan, Tetapi disisi lain menimbulkan berbagai 
keprihatinan seperti timbulnya eksploitasi sumberdaya alam yang tidak mempertimbangkan aspek kelestarian dan keberlanjutan telah menimbulkan kerusakan lingkungan, pertumbuhan ekonomi yang tidak disertai upaya distribusi pendapatan secara merata menyebabkan kesenjangan, di mana kelompok kaya menikmati nisbah pembangunan dengan lebih baik tetapi kelompok miskin semakin terpuruk dan tenggelam dengan rasa ketidak berdayaannya. Secara nasional fokus pembangunan dititikberatkan pada pembangunan sarana dan prasarana pendukung besar di perkotaan, dengan harapan akan memberi akibat terhadap gairah pelaku pasar. Bersamaan dengan diterapakan pula kebijakan efek penetas ke bawah dengan penghantar sumberdaya pembangunan yang akibatnya sampai pada kurung waktu sejak tahun 60an keadaan tersebut membawa kelemahan pada tidak berkembangnya aktifitas di wilayah lokal terutama lemahnya aktifitas ekonomi di pasar lokal. Kelemahan lain adalah pada kemampuan sistem administrasi lokal memberi pelayanan yang memuaskan kepada masyarakatnya. Kedua kelemahan tersebut menyebabkan adanya kelemahan pada masyarakat lokal termasuk rumah tangga miskin lokal. (Ohama, 2001)

Pemerintah menetapkan UU 19 tahun 2013 Tentang Perlindungan dan Pemberdayaan Petani. Undang-Undang tersebut menimbang bahwa peraturan perundang-undangan yang berlaku saat ini belum mengatur perlindungan dan pemberdayaan petani secara komprehensif, sistemik, dan holostik. Implementasi UU Nomor 19 tahun 2013 berupa bentuk kebijakan yang dapat di berikan untuk melindungi kepentingan petani, antara lain pengaturan impor komoditas pertanian sesuai dengan musim panen dan/atau kebutuhan konsumsi di dalam negeri, penyediaan sarana produksi serta subsidi sarana produksi, kemudian penetapan tarif bea masuk komoditas pertanian, serta penetapan tempat pemasukan komoditas pertanian dari luar negeri dalam kawasan pabean (Instansi dalam kawasan yang mengawasi, memungut dan mengurus bea masuk impor dan ekspor).

Petani di Indonesia merupakan masyarakat yang sebagian besar masuk dalam kelompok penduduk miskin saat ini. Sekitar 55\% dari jumlah penduduk miskin di Indonesia adalah petani, dan 75\% dari petani miskin itu adalah petani tanaman pangan. Fakta tersebut adalah bagian sangat strategis dalam peta 36 juta penduduk miskin di Indonesia (17\% dari total penduduk). Karena lebih dari 15 juta orang miskin tersebut berada di daerah pedesaan dan umumnya berhubungan langsung dalam sektor pertanian (Media Komunikasi dan Informasi No. 46/XV Januari 2006). Kemiskinan lazimnya dilukiskan sebagai kurangnya pendapatan untuk memenuhi kebutuhan (Daraba, 2015).

Tingkat kemiskinan di Sulsel tampaknya akan meningkat disebabkan tingkat pengangguran terbuka (TPT) terus meningkat. Kabupaten Jeneponto merupakan salah satu kabupaten dengan taraf pertumbuhan kesejahteraan relatif tertinggal dibanding kabupaten lainnya dan menempati urutan nomor satu pada tahun 2014 kategori daerah tertinggal (BPS 2010).

Dikalangan masyarakat tani kegiatan kolektif seperti berkelompok telah berlangsung lama baik dalam aksi kolektif tradisioanal seperti gotong royong, arisan dan mengurus aset milik bersama seperti mesjid dan kuburan. Ibu-ibu sering mengadakan arisan terutama di pasar tradisional. Kelembagaan seperti ini memperlihatkan bentuk interaksi, tata hubungan dan kesepakatan yang lebih mengutamakan, persamaan dan keadilan antara anggota yang satu dengan anggota yang lain. Pada masyarakat bugis makassar termasuk di Kabupaten Jeneponto, yang lama di kenal adalah prinsip a bulo si batang, acera sitongka-tongka, yakni prinsip yang berarti kebersamaan, demikian seperti sebatang bambu, saling membantu dan senantiasa merasa senasib dan sepenanggungan.

Pentingnya kajian ini didasari dari penelitian Dumasari dan Mulia (2009) yang mengungkap bahwa mayoritas petani miskin sedang Kesulitan menyelesaikan persoalan pengembangan diversifikasi nafkah produktif untuk kepentingan memperoleh tambahan pendapatan (extra income). Meski telah menerapkan ragam bentuk problem focus coping untuk menyelesaikan sederet permasalahan pengelolaan adopsi teknologi pada usaha tani dan tambak ikan air tawar yang berbiaya produksi tinggi namun petani miskin dipedesaan terintangi berbagai faktor sosial ekonomi lain seperti keterbatasan modal, keterjaminan 
pasar dan bahan baku, minimnya sarana dan prasarana usaha produktif, kekurangmampuan adopsi teknologi inovatif berbiaya murah dan mudah dilakukan serta ramah lingkungan.

Dalam melakukan pemerdayaan masyarakat tentunya harus menggunakan pendekatan kelompok, karena secara sendiri-sendri masyarakat miskin kesulitan dalam memecahkan masalah yang di hadapi, dan juga lingkup bantuan menjadi terlalu luas jika penanganannya di lakukan secara individu (Syahyuti, 2006).

Sejalan dengan permasalahan-permasalahan terkait dengan keluarga petani miskin khususnya yang ada di kabupaten Jeneponto, maka kajian ini bertujuan untuk mengidentifikasi masalah keberdayaan masyarakat keluarga petani miskin dan peran Kelembagaan Komunitas dalam Pemberdayaan Rumah Tangga Petani Miskin di Desa Kapita Kecamatan Bangkala Kabupaten Jeneponto.

\section{METODE}

Penelitian ini menggunakan pendekatan kualitatif dengan jenis penelitian studi kasus. Pada tahap awal penelitian ini melakukan pencacahan terhadap rumah tangga miskin yang akan dijadikan subjek penelitian pada situs penelitian. Fokus Penelitian, yaitu pemberdayaan masyarakat pada kelembagaan komunitas rumah tangga petani miskin di Desa Kapita Kecamatan Bangkala Kabupaten Jeneponto. Adapun informan penelitian ditentukan secara purposive yakni informan ditentukan secara sengaja kepada orang yang lebih paham permasalahan pemberdayaan masyarakat yaitu aparat terkait pada Dinas Tenaga Kerja Transmigrasi dan Sosial, Dinas Pertanian, dan Badan Pemberdayaan Masyarakat dan Pemerintahan Desa. Informan lainnya adalah masyarakat yang menjadi obyek penelitian yaitu rumah tangga petani kategori miskin. Pengumpulan data dilakukan melalui wawancara secara langsung dengan informan penelitian, observasi lapangan dilakukan untuk mengetahui kondisi riil rumah tangga petani miskin, dan dokumentasi yakni mengumpulkan data melalui penelusuran bahan-bahan tertulis atau bahan pustaka lainnya yang ada kaitannya dengan objek yang diteliti. Pengabsahan data penelitian dilakukan dengan menggunakan treangulasi baik melalui treangulasi sumber maupun data. Analisis data penelitian yang digunakan sesuai dengan prosedur analisis kualitatif, dan selanjutnya penyajian data dalam bentuk deskriptif dan penjelasan naratif

\section{HASIL DAN PEMBAHASAN}

Hasil penelitian menunjukkan bahwa kondisi kemiskinan yang ada pada desa daerah penelitian menunjukkan bahwa terdapat beberapa proses yang dilakukan dalam rangka pemberdayaan rumah tangga miskin yakni meliputi dimensi-dimensi sebagai berikut:

\section{a. Enabling Potential (Pengembangan Potensi)}

Kondisi kemiskinan yang harus di tanggulangi mencakup banyak segi. Pemilikan sumber daya yang tidak merata, kemampuan masyarakat yang terbatas dan ketidak samaan kesempatan dalam menghasilkan akan menyebabkan keikutsertaan dalam pembangunan tidak merata. Ini semua pada gilirannya menyebabkan perolehan pendapatan tidak seimbang dan selanjutnya menimbulkan struktur masyrakat yang timpang.

Secara umum permasalahan kemiskinan dan ketidakberdayaan disebabkan oleh dua faktor utama yang saling mengkait satu sama lain, yaitu : Faktor internal dan faktor eksternal. Faktor internal menyangkut permasalahan dan kendala yang berasal dari dalam individu atau masyarakat miskin di desa kapita, seperti : rendahnya motivasi, minimnya modal, lemahnya penguasaaan aspek manajemen dan teknologi. Sementara faktor eksternal penyebab kemiskinan dan ketidakberdayaan adalah belum 
kondusifnya aspek kelembagaan yang ada, Disamping masih minimnya infrastruktur dan daya dukung lainya sehingga potensi-potensi yang dimilki oleh masyarakat tidak dapat ditumbuh kembangkan.

Pemberdayaan masyarakat dilaksanakan melalui pengembangan masyarakat, dan yang kedua pengorganisasian masyarakat. Apa yang dikembangkan dari masyarakat yaitu potensi atau kemampuanya dan sikap hidupnya. Kemampuan masyarakat dapat meliputi antara lain kemampuan untuk bertani, berternak, melakukan wirausaha, atau keterampilan-keterampilan membuat home industry dan masih banyak lagi kemampuan dan keterampilan masyarakat yang dapat dikembangkan. Berdasarkan hasil wawancara dengan bapak HD dilapangan pada saaat melakukan penelitian :

"Dinas Transmigrasi tenaga kerja dan sosial ini sudah banyak program yang direalisasikan di desa kapita ini seperti PKH (Program keluarga harapan, PSKS (Program simpanan keluarga sejahtera), ASODKB (Asistensi sosial orang dengan kecacatan berat), Program lanjut Usia, program pelatihan dan kursus seperti : Las Listrik, Pertukangan, Ukir, tata arias, menjahit. Disini kami ada ruang khusus tempat kurusus namun kapita belum pernah ada pesertanya yang lolos seleksi untuk ikut serta disini, karena kita kasih kursus disni, karena kita kasih kursus orang sesuai dengan hasil seleksi yang telah kami lalukan ( Senin, 26 Oktober 2015 pukul 09.30 WITA)

\section{b. Empowering Potential (Penguatan Potensi)}

Pemberian pendidikan dan pelatihan secara sistematis mengenai keterampilan khusus yang dibutuhkan sesuai dengan potensi alam yang ada di sekitanya. Berdasarkan hasil wawancara dengan bapak HK bahwa:

"Ada juga program dari kementrian pemberdayaan desa memberikan alat dan di kursuskan. Tapi dikapita belum pernah ada dikirim kelompok masyarakat pelatihan.seleksi disesuaikan potensi desa, misal di Desa Kelara produksi bawang merah ini kita lakukan pelatihan disana dilatih untuk bisa dikemas bawang putih ini bisa dijadikan nilai jualnya bisa tinggi misalnya digoreng dikemas dan dijual"' (Senin, 26 Oktober 2015)

Berdasarkan hasil wawancara diatas dapat diketahui bahwa pada badan pemberdayaan masyarakat dan pemerintahan desa belum pernah mengirim satu kelompok pun untuk ikut pelatihan ataupun kursus, alasanya hanya karena masalah potensi desa yang ada di kapita. Padahal kalau penulis melihat dan observasi dilapangan melihat potensi alam desa kapita cukup ada yakni jagung juga bisa dimanfaatkan untuk diberikan pelatihan kepada kelompok masyarakat tentang bagaimana cara membuat kue dodol jagung, dan bisa juga jagungnya dikemas dalam bentuk jagung bakar atau jagung masak terus dijual di pinggiran perkotaan atau di pasar. Sesuai dengan hasil wawancara dengan bapak RG bahwa :

" Kita sudah lakukan pemberdayaan dimasyarakat, di dinas pertanian ada program bibit, peralatan pertanian dan mesin pertanian. Dan sekarang kami selalu berusaha memberdayakan potensi masyarakat lewat kegiatan bertaninya. Sudah banyak terealisasi mesin hand traktor dan mesin pertanian lainya di kapita. Malah sekarang diharapkan sebenarnya para kepala desa bisa akomodir biar bisa masuk anggaran desa. Ini program pusat karena program pelatihan belum tersentuh semua desa. Karena terbatasnya permintaan dari pusat. Kai selalu mengadakan rapat dengan kepala desa. Apalagi di desa kapita bagus hasil pertanianya persoalannya begini, pemerintahan bukan mengurus kampong perkampung cuma kami selalu adakan rapat dengan kepala kepala desa, hanya saja kepala desa yang kadang yang kadang tidak pernah memberika laporan mengenai perkembangan masyarakat dan kelompok kelompok masyarakat dan coordinator pendamping desanya, sehingga kapita tidak pernah medapat kesempatan untuk diikuti pelatihan dan kursus" (Selasa, 26 Oktober 2015 pukul 11.40 WITA)

Berdasarkan hasil wawancara diatas bahwa dinas pertanian menilai kapita memiliki potensi alam yang bagus namun upaya mereka untuk mengembangkan potensi senantiasa dilakukanya serta alat alat pertanian sudah terealisasi namun hubungan komunikas dengan kepala desa kurang, sehingga kepala Badan Pemberdayaan Masyarakat Dan Pemerintahan Desa tidak pernah menerima laporan profil desa dan 
keadaan lembaga yang ada di kapita sehingga upaya mengembangkan potensi masyarakat disana sangat sulit sebab kami tidak tahu kelompok mana yang kompeten dan bisa untuk diikuti pelatihan keterampilan dibidang pertanian.

\section{c. Protect (Melindungi)}

Dalam proses pemberdayaan, harus di cegah yang lemah, oleh karna kekurang berdayaan dalam menghadapi yang kuat. Oleh karena itu, perlindungan dan pemihakan kepada yang lemah amat mendasar sifatnya dalam konsep pemberdayaan masyarakat. Melindungi tidak berarti mengisolasi atau menutupi dari interaksi , karena hal ini justru akan mengerdilkan yang kecil dan melunglaikan (Menindas) yang lemah. Melindungi harus di lihat sebagai upaya untuk mencegah terjadinya persaingan yang tidak seimbang, serta ekspoitasi yang kuat atas yang lemah. Pemberdayaan masyarakat pemberian (chairity). Karena pada dasarnya setiap apa yang dinikmati harus dihasilkan atas usaha sendiri (yang hasilnya dapat di pertikarkan dengan pihak lain) dengan demikian tujuan akhirnya adalah masyarakat, memampukan, dan membangun kemampuan untuk memajukan diri kearah kehidupan yang lebih baik secara berkasinambungan. Berdasarkan hasil wawancara dengan BT bahwa :

"Kepala desa kami saja tidak nampak hasil kerjanya di Desa Kapita ini, sangat menjaga jarak dengan masyarakat terutama organisasi karang taruna yang sekarang saya pimpin ini. Dia angat acuh tak acuh dengan kami, dia tidak pernah tau kondisi lembaga kami selama 2 Periode ini tidak ada sumbangsih kepala desa terhadap lembaga kami. Padahal pemerintahan Desa yang harus paling utama mampu memberikan perlindungan kepada kelompok-kelompok yang ada agar tidak terpuruk dalam keadaan rumah tangga yang tidak mampu menyelesaikan masalah sehingga pemerintahan yang harus melindungi masyarakat yang memiliki masalah social, ekonomi dan budaya. (Jum'at, 30 oktober 2015)

Ditambahkan SY :

"Kami dusun sini tidak pernah satu kalipun mengunjungi kami membentuk perlindungan jika ada dari kami memiliki masalah. Kami juga selalu ingin membuat kelompok tapi didusun lain saya yang mendapat banyak kesempatan itu, sedangkan kami didusun yang terpencil ini tidak ada satupun kelompok yang terbentuk. (Selasa 20 oktober 2015 pukul 09.30 WITA )

Berdasarkan hasil wawancara diatas bahwa kelompok masyarakat petani selama ini sangat sulit mendapat perlindungan sebab pemerintah desa saja acuh tak acuh tentang kondisi perkembangan kelompok masyarakat yang ada. Apalagi SKPD terkait yang ingin memperhatikan sejauh mungkin perkembangan kondisi kelompok yang terbentuk didesa ini untuk diupayakan pembentuk kelembagaan komunitas yang kuat dan kokoh

Seperti yang diungkapkan JM bahwa :

"Kami di dusun ini sudah miskin tambah miskin lagi, sebab yang rata rata dimasukan kedalam kelompok kebanyakan orang orang luar dusun bonto la 'bua kami disini hanya punya pengkulak saja yang membeli hasil panen kami dengan harga yg tinggi tidak ada satupun kelompok yang mampu mefasilitasi kami dalam hal memberdayakan potensi kami disini, padahal disini di dusun boleh dikata banyak yang miskin namun kemampuan untuk bekerja dan berusaha sangat tinggi apalagi banyak ibu ibu yang tau membuat kue kue tradisional yang enak nikmat dan gurih hanya saja tidak yang memfasilitasnya kami merasa tidak terlindungi oleh pemerintah setempat bahkan hasil yang kami peroleh setiap bulanya belum cukup untuk membiayai kebutuhan hidup sehari hari saya dengan istri dan anak anak saya sebab kami bergantung sama pemilik modal dan tidak ada satupun kami biasa tabung (Sabtu,31oktober 2015)

Berdasarkan hasil wawancara diatas bahwa masih ada rumah tangga miskin yang terabaikan dan pernah disentuh oleh pemberdayaan kelompok bahkan pemahaman dan pengetahuan pun kurang tentang kelompok itu seperti apa kehidupan sehari hari bergantung sama milik modal dan tidak pernah merasa terlindungi oleh pemerintahnya. 
Sama halnya dengan SY salah satu tokoh masyarakat dusun pokongan mengatakan bahwa :

" Saya andaikan ada kelompoku juga mungkin saya bisa menjual kue sebab kami disini belum banyak yang punya kelompok dan kami juga tidak tau membentuk kelompok kelompok sebab kami hanya teman SD dan saya bisa lakukan hanya membuat kue kue kering itupun saya tidak tau harus mengembangkan dimulai dari mana dan siapa yang mau membiayai modal awalku dulu. Pemerintah desa mana ada yang mau perhatian rumah tangga kami pasti yang diperhatikan hanya dusun di luar luar saja" (sabtu 30 Oktober 2015 )

Berdasarkan hasil wawancara diatas bahwa saya satu tokoh masyarakat dusun pokanga ini menganggap pemerintahan tidak peduli dirinya dan kondisinya sehingga tidak pernah merasakan perubahan yang baik pada rumah tangganya yang dari dulu punya niat punya usaha kecilan, namun pemerintah tidak pernah memperhatikan masyarakat miskimn dan kecil seperti dia.

Sesuai dengan temuan-temuan penelitian di atas, maka informasi yang diperoleh dari hasil wawancara tersebut dapat dibahas sebagai berikut:

a. Enabling (Mengembangkan Potensi)

Menurut Gunawan (1999) bahwa Pemberdayaan masyarakat dilaksanakan melalui pengembangan masyarakat (enabling), Apa yang dikembangkan dari masyarakat yaitu potensi atau kemampuanya dan sikap hidupnya. Kemampuan masyarakat dapat meliputi antara lain kemampuan untuk bertani, berternak, melakukan wirausaha, atau keterampilan-keterampilan membuat home industry dan masih banyak lagi kemampuan dan keterampilan masyarakat yang dapat dikembangkan

Para informan dari SKPD terkait mengatakan bahwa Desa Kapita belum pernah tersentuh pengadaan untuk dikirim kursus ketrampilan baik menjahit, perbengkelan, tat arias, dan kursus membuat kue dari potensi alam yang ada di Desa Kapita seperti pemanfaatan jagung untuk dibuat dodol dan bawang merah untuk dikemas dan dijual/dipasarkan.

Namun peneliti melihat potensi alam memang di Desa Kapita cukup membantu dan bermanfaat, sehingga pemerintah seharusnya lebih giat dan memperhatikan masyarakat yang berpotensi di Desa Kapita untuk diberikan kursus dan pelatihan. Jalan keluar terbesar yang harusnya dibenahi oleh SKPD terkait dalam hal ini Dinas Sosial, Dinas Pertanian, dan Badan Pemberdayaan Masyarakat dan Pemerintahan Desa. Sebab, ppengembangan potensi masyarakat disana mampulah dimanfaatkan jika pemerintah ingin bekerja keras untuk memberikan peluang dan kesempatan kepada kelompok-kelompok yang ada di Desa Kapita.

b. Empowering (Memperkuat Potensi)

Penguatan Potensi yang ada di Desa Kapita menurut hasil wawancara para informan yakni SKPD terkait mengatakan bahwa Dinas Sosial senantiasa memberikan bantuan kepada kelompok yang ada hanya saja kelompok yang ada di Desa Kapita sangat sulit untuk di deteksi hubungan kekerabatannya sebab kami juga sangat terbatas waktu untuk mengunjungi lokasi desa kapita. Sehingga para SKPD terkait hanya bias memnyimpulkan bahwa penguatan potensi yang ada pada kelompok di Desa Kapita memang sangat bagik untuk diterapkan hanya saja jalinan komunikasi antara Kepala Desa dengan SKPD terkait sangat kurang sehingga kami sibuk mengurus desa yang lebih intens menjalin komunikasi dengan dinas terkait. Pembangkitan partisipasinya juga masih kurang ini terlihat dari pemaparan sekrteris camat yang mengatakan bahwa kalau ada musyrembang yang datang yang itu-itu saja, sehingga peneliti mencoba menyimpulkan bahwa di Desa Kapita sangat perlu sinergitas antara aparat Desa, Pendamping Desa, dan SKPD terkait dalam menguatkan potensi masyarakat/kelompok yang ada di Desa Kapita.

Peneliti menghanjurkan agar kiranya pemerintah senantiasa member peringatan kepada aparat desa kapita agar lebih intens memperhatikan kondisi keberdayaan masyarakatnya khususnya pada kelompok rumah tangga miskin yang ada. Rasa kebersamaan dan rasa bertanggung jawab perlu sekali ditumbuhkan dalam kelompok yang ada seperti kelompok tani, ternak kambing, arisan pasar tradisional, barang campuran dan meubel serta perbengkelan. Keenam kelompok ini tentunya jika dikuatkan dan 
diberi daya berupa motivasi, semangat, dan pemberian pelatihan dan kursus akan jadi lebih berdaya dan terampil. Sehingga mereka mampu membawa kelompoknya kearah yang lebih mandiri dan tidak selalu bergantung sama pemerintah dan komponen desa lainnya.

Hasil penelitian ini sejalan dengan teori yang diungkapkan Sumodiningrat (2002) bahwa Memperkuat potensi atau daya yang dimiliki masyarakat (empowering). Dalam rangka ini di perlukan langkah-langkah lebih positif, selain dari hanya menciptakan iklim dan suasana. Perkuatan ini meliputi langkah-langkah nyata, dan masyarakat penyediaan berbagai masukan (input), serta pembukaan akses di dalam berbagai peluang (opportunities) yang akan membuat masyarakat menjadi berdaya. Pemberdayaan bukan hanya meliputi pengaturan individu anggota masyarakat, tetapi juga pranata - pranatanya. Menanamkan nilai-nilai budaya modern, seperti kerja keras, hemat, keterbukaan dan rasa bertanggung jawaban adalah bagian pokok dari upaya pemberdayaan ini. Demikian pula juga pembaharuan institusi istitusi sosial dan pengintegrasinya ke dalam kegiatan pembangunan serta peranan masayarakat didalamnya. Yang terpenting disni adalah peningkatan partisipasi rakyat dalam proses pengambilan keputusan yang menyangkut diri dan masyarakatnya. Oleh karena itu, pemberdayaan masyarakat sangat erat kaitannya dengan pemantapan, pembudayaan dan pengalaman demokrasi.

\section{c. Protect (melindungi)}

Memberdayakan mengandung pula arti melindungi. Dalam proses pemberdayaan, harus di cegah yang lemah menjadi bertambah lemah, oleh karena kekurang berdayaan dalam menghadapi yang kuat oleh karena itu, perlindungan pemihakan kepada yang lemah amat berdasar sifatnya dalam konsep pemberdayaan masyarakat. Melindungi tidak berarti mengisolasi atau menutupi dari interaksi, karena hal ini jutru akan mengerdilkan yang kecil dan melunglaikan yang lemah. Melindungi harus di lihat sebagai upaya untuk mencegah sebuah persaingan yang tidak seimbang serta ekspoitasi yang kuat atas yang lemah. Pemberdayaan masyarakat pemberian (charity). Karena, pada dasarnya satiap apa yang dinikmati harus di hasilkan atas usaha sendiri (yang hasilnya dapat di pertikarkan dengan pihak lain). Dengan demikian tujuan akhirnya adalah memandirikan masyarakat, memampukan, dan membangun kemampuan untuk memajukan diri kearah kehidupan yang lebih baik secara berkesinambungan. (Sumodiningrat dalam Gunawan, 2002).

Hasil penelitian dari informan SKPD terkait mengatakan pihaknya selalu terus berupaya memberikan layanan yang maksimal, hanya saja hubungannya dengan kepala desa dan pihak kelompokkelompok yang ada di Desa Kapita sangat renggang sehingga sulit melakukan koordinasi yang baik ke desa kapita. Hal ini membuat usaha untuk melakukan koordinasi dan pengawasan sangat sulit dilakukan pihak SKPD sebab kesenjangan hubungan aparat desa dengan LSM, Lembaga desa dan SKPD terkait belum mampu membuka interaksi sosial yang baik.

Melihat hal ini peneliti menyimpulkan bahwa memberdayakan dalam hal melindungi memang tidak segampang yang dirasakan. Hal melindungi terjadinya sebuah persaingan yang tidak sehat dan konflik antar kelompok yang ada membuat SKPD harus lebih kerja keras membangun hubungan yang baik ke aparat desa, dan kalau perlu lebih tegas lagi dalam soal pengaturan warga dan pengaturan kelompok. Dalam hal ini kelompok yang ada dan yang sudah berembang diberikan kemampuan dan upaya untuk berkembang lewat kegiatan-kegiatan, kursus dan pelatihan agar mampu lebih terampil dan diawasi secara langsung oleh pemerintah dan lsm pun bekerja sama baik dengan semua stakeholder yang ada agar mampu melindungi masyrakat kelompok yang ada di Desa Kapita seperti kelompok tani dalam penggunaan hand traktor, kelompok ternak kambing dalam pengembangan usaha kambingnya agar berdaya guna dan bermanfaat untuk kesejahteraan masyarakat miskin yang ada. 


\section{KESIMPULAN}

Hasil penelitian dengan beberapa dimensi yang di teliti maka dapat ditarik kesimpulan bahwa : Permberdayaan yang dilakukan oleh pemerintah belum sepenuhnya berjalan baik, efek positif dan manfaatyang dirasakan masyarakat kelompok petani terletak pada penyaluran dana bantuan yang cukup membantu memenuhi kebutuhan masyarakat pada desa bersangkutan. Namun, hal ini tidak membuat anggota kelompok mandiri. Selain itu dapat dilihat beberapa program pemberdayaan yang di lakukan oleh pemerintah belum maksimal, hal ini dapat dilihat program yang dilakukan beberapa SKPD di Kabupaten Jeneponto belum di rasakan manfaatnya oleh berbagai masyarakat rumah tangga miskin. Seperti program pembentukan KUBE yang dilakukan oleh SKPD terkait, kenyataanya belum mampu menjadikan kelompok yang kuat dan melembaga. Program bantuan hand traktor oleh Dinas Pertanian belum cukup membantu, sebab masih ada anggota yang merasa tidak adil dalam penggunaan hand traktor tersebut, seperti yang dirasakan oleh kelompok tani di Desa Kapita. Penyaluran bibit dan pupuk tanaman yang masih dikeluhkan lama dan lambat penyalurannya. Pada kelompok perbengkelan dikeluhkan pelatihan dan kursus yang selama ini tidak pernah kelompoknya diikutkan di daerah untuk kursus perbengkelan. Disamping itu juga, kelompok barang campuran sangat sulit untuk menjalin kerjasama yang efektif dengan anggota-anggotanya. Selain itu, belum adanya pusat kegiatan pembinaan dan pelatihan serta layanan kepada masyarakat yang merasa belum terlayani dengan baik. Tidak terdapat koperasi sebagai bidang usaha yang di jadikan sebagai pusat simpan pinjam oleh masyarakat ketika ada keperluan yang mendesak sebagai penyebab kebanyakan yang meminjam kepada tengkulak atau pemilik modal. Selanjutnya pada sarana dan prasarana seperti dari segi pendidikan, kesehatan, sosial ekonomi dapat di katakan cukup baik sebab bantuan dana dari Dinas Sosial pertriwulan sebesar 300 ribu anak sesuai tingkatan sekolah dan dengan syarat harus rajin masuk sekolah.

\section{DAFTAR PUSTAKA}

[1]. A., Djumino, Wahyudin, M, 2002, Pengaruh Kepemimpinan dan Motivasi Terhadap Kinerja Karyawan, Tesis, Tidak dipublikasikan

[2]. Badan Pusat Statistik, 2011. Perhitungan dan Analisis Kemiskinan Makro Indonesia Tahun 2011, (BPS : CV Nario Sari) hal 19-20

[3]. Charles AT. 2001. Sustainable fishery system. Canada : Blakwell Science Ltd.370p

[4]. Craig, G. and Mayo M. (eds) (1995) Community Empowerment. A Reader in Participation and Development. London : Zed Books. Pp.1-11.

[5]. Creswell, 1998. Empowerment and development, diterjemahkan Rahayu, Jakarta : Grasindo utama

[6]. Daraba, Dahyar, 2015. Faktor-faktor yang Mempengaruhi Keberhasilan Program Pemberdayaan Masyarakat Miskin di Kecamatan Polongbangkeng Utara Kabupaten Takalar Provinsi Sulawesi Selatan. Jurnal Sosiohumaniora, 17 (2), 168-169

[7]. Dault, A .2008. Pemuda dan Kelautan. Jakarta : Pustaka Cidesindo 
[8]. Dumasari dan Oetami, D.H. 2012. Perilaku petani miskin dalam pengelolaan diversifikasi panan on beras di pedesaan. Laporan Hasil Penelitian Hibah Program Studi. LPPM Universitas Muhammadiyah Purwokerto.

[9]. Sudibyo dan Sudayanta.2002. Pemberdayaan Masyarakat Pedesaan Materi Pelatihan Pengelolaan Hutan Mangrove Information Centerproject, Kerja Sama JICA dan Departemen Kehutanan di Bali, September 2002. Pusat Diklat Kehutanan, Bogor.

[10]. Suharto, Suharto.2009. Kemiskinan dan Perlindungan Sosial di Indonesia : Menggagas Model Jaminan Sosial Universal Bidang Kesehatan. Bandung : CV Alfaberta.

[11]. Sumaryadi, I Nyoman. 2005. Perencanaan Pembangunan Daerah Otonom dan Pemberdayaan Masyarakat. Jakarta : Citra Utama.

[12]. Sumodiningrat, Gunawan dkk. 1999. Kemiskinan, Teori, Fakta dan Kebijakan. Jakarta : OMPAC

[13]. Syafiuddin S. 2008. Optimalisasi Penanggulangan Kemiskinan Dengan Menggunakan Pendekatan Parcitipatory Assessment and Monitoring di Kota Makassar. Penelitian Agroekonomi vol 26 No 2 , tanggal 2 Desember 2008, p.82-91 (PPAM) Lembaga Penelitian Universitas Muhammadiyah Makassar .

[14]. Syafiuddin, S., Mahsyar, A. (2016). Condition and Characteristics of Poor Farmer Households in the Perspective of Participatory Local Social Development in Jeneponto Regency, South Sulawesi, Indonesia. European Journal of Social Sciences, 51(1), 133-140.

[15]. Uphoff, Norman.1986. Lokal Institutional Development : An Analytical Sourcebook with cases. West Hartford, Conn Kumarian Press.

[16]. Widayanti. 2003. Kajian Kelembangan Materi Semikola. Studi/Kajian Perda Sektor Kelautan dan Perikanan Propinsi Sulawesi Selatan. LP3MPK Makassar

[17]. Wilson,Terry. 1996. The Empowerment Manual. Grower Publishing Company. London

[16]. Zulkifli. 2007. Kehidupan Sosial Masyarakat. Pustaka Sinar Harapan. Jakarta 